\title{
A CARIAN INSCRIPTION FROM MYLASA
}

\begin{abstract}
In the following discussion of a Carian inscription on an oinokhoe from Mylasa, dated to the 7th century BC, the values of the signs of the Carian alphabet as established by me in my contribution entitled Carian: On the Greek-Luwian Interface (Živa Antika 68, 5$24)$, are put further to the test. In doing so, it turns out that we are confronted here with an object bilingual in which the vase on which the inscription is written is mentioned. Apart from this salient feature, the inscription consists of a run-of-the-mill dedicatory text.
\end{abstract}

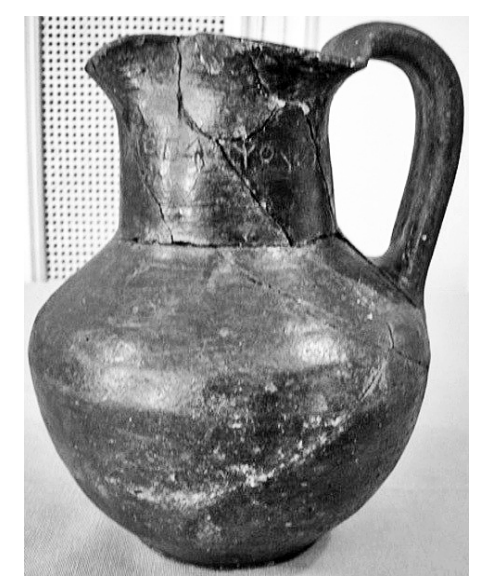

Fig. 1. Oinokhoe from Mylasa (Türkteki \& Tekoğlu, Une inscription Carienne sur oenochoé, 103, Fig. 1 [upper left]).
After the publication of my paper on Carian, ${ }^{1}$ I came across a publication of a completely preserved Carian inscription from the Sadberk Hanım museum in İstanbul by Sinem Türkteki and Recai Tekoğlu of 2012. This inscription, inscribed on the neck of an oinokhoe catalogued as inv. nr. ARK 919-14806 (Fig. 1) and reported to originate from clandestine excavations at Damliboğaz (= classical Hydai), $7 \mathrm{~km}$. west of Milas (= classical Mylasa), ${ }^{2}$ therefore provides an excellent opportunity to put the values for the signs as proposed by me (Fig. 3) further to the test.

The inscription, which, as I will elaborate below, presumably belonged to a sanctuary in the region of Mylasa, is dated by its publishers to the 7th century $\mathrm{BC}{ }^{3}$ This is very early, as Carian inscriptions from Caria itself (as opposed to those from Egypt) thus far known date to

\footnotetext{
${ }^{1}$ Woudhuizen, Carian: On the Luwian-Greek.

${ }^{2}$ Türkteki \& Tekoğlu, Une inscription Carienne sur oenochoé, 101.

${ }^{3}$ Türkteki \& Tekoğlu, Une inscription Carienne sur oenochoé, 102.
} 
the period of the 6th to 4 th century BC. ${ }^{4}$ Closest comparative data are therefore provided by the Carian inscriptions from Sardis and Smyrna also datable to the 7 th century $\mathrm{BC}^{5}{ }^{5}$ though in these cases the Carian nature of the inscriptions is questionable as it is also possible that we are simply dealing here with an early phase of the Lydian script.

The inscription, which runs in retrograde direction of writing, consists of 31 letters in sum, one of which, the rho, is added later on top of the line just like the only instance of the word divider in the form of a vertical stroke (Fig. 2).

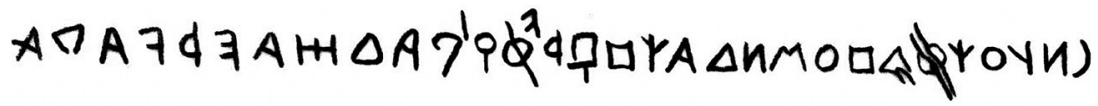

Fig. 2. Carian inscription on the oinokhoe

(Türkteki \& Tekoğlu, Une inscription Carienne sur oenochoé, 102).

In the legend only signs originating from the Phoenician alphabet are used (Fig. 3), and not ones from the category distinguished by me as originating from the Cypro-Minoan Syllabary and/or the Cretan Linear script. ${ }^{6}$

From an epigraphic point of view, it deserves our attention that in the legend there are used two forms of delta, one in form of an upright triangle and the other of a semi-circle attached to a vertical hasta. Furthermore, omicron occurs in both rounded and square variant. Next, the qoph sign, used for both the expression of the original value $q$ and the secondary value $i$, also appears in rounded and square variant as well as in form of a triangle pointing downwards without hasta. Finally, khi is only used for the expression of its original value $\chi$ and not for its secondary value $\tilde{e}$.

If allowance be made for the observation that the damaged sixth sign is omicron instead of $s$, we arrive at the following transliteration and translation (see commentary below) of the legend on the oinokhoe from Mylasa:

\section{Oinokhoe from Mylasa, 7th century BC (dedicatory)}

cn-uo xodoośn daxoídroil "This pouring vessel for a water-libation, padșa edraqa Pedasa has dedicated."

Table I. Text in transliteration and translation.

For our understanding of the contents of the inscription it is of prime importance that its structure is of a highly transparent nature. Thus it starts with the two-partite object of which both elements are characterized by the $\mathrm{A}(\mathrm{m} / \mathrm{f}) \mathrm{sg}$. in $-n$, continues with the indirect object

\footnotetext{
${ }^{4}$ Türkteki \& Tekoğlu, Une inscription Carienne sur oenochoé, 100.

${ }^{5}$ Türkteki \& Tekoğlu, Une inscription Carienne sur oenochoé, 107.

${ }^{6}$ Woudhuizen, Carian: On the Luwian-Greek, 8, Fig. 2.
} 
in $\mathrm{D}$ sg. $-i$, which sequence in turn is followed after the only instance of the word divider by the combination of the dedicator in endingless $\mathrm{N}(\mathrm{m} / \mathrm{f}) \mathrm{sg}$. and the verb marked by the ending of $3 \mathrm{rd}$ pers. $\mathrm{sg}$. of the past tense in -qa.

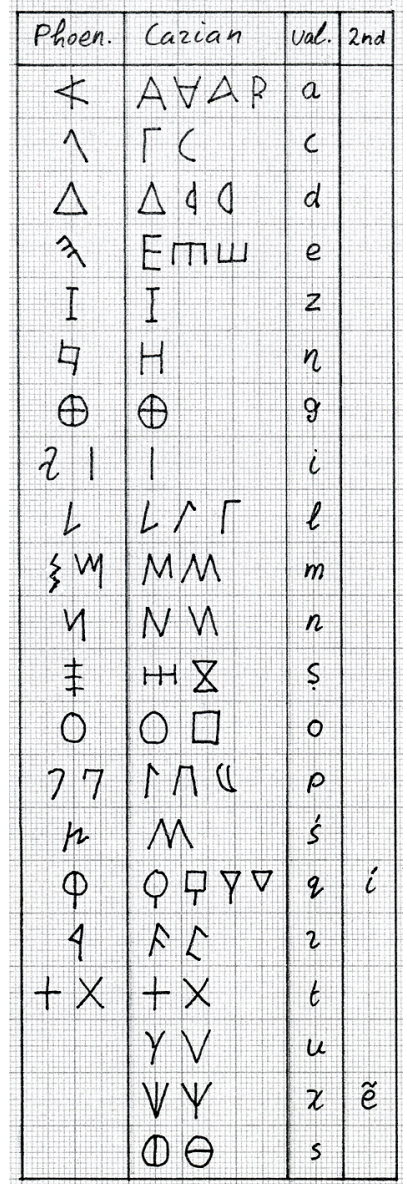

3. Carian signs originating from the Phoenician alphabet

(Woudhuizen, Carian: On the Luwian-Greek, 7, Fig. 1).
To go into further detail, the following elements can be distinguished, discussed in their order of appearance in the commentary below.

\section{COMMENTS}

$c n: \mathrm{A}(\mathrm{m} / \mathrm{f}) \mathrm{sg}$. in $-n$ of demonstrative pronoun $c$ - "this". This demonstrative, which corresponds to Etruscan $c(a)-{ }^{7}$ ultimately originates from Hittite $k a$ - "this" $(<$ Proto-Indo-European [= PIE] $* k i-){ }^{\prime}{ }^{9}$

$-u o$ : introductory particle corresponding to cuneiform Luwian -wa, Luwian hieroglyphic $w a-,-w a$, Lycian -we, Lydian $f a-,{ }^{10}$ and Etruscan $v a-, f a-{ }^{11}$

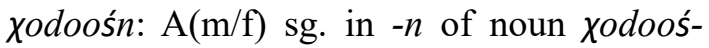

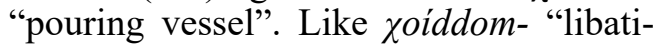
on-vessel" from C.xx 2 of uncertain origin, ${ }^{12}$ this noun is of composite nature. The first element $\chi o$ - or $\chi o i^{-}$is related to

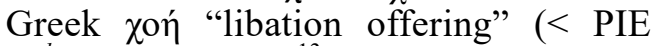
$* \hat{g}^{h} e u$ - "to pour"), ${ }^{13}$ whereas the second element dooś- or ddom- originates from PIE * deh $3^{-}$"to give", ${ }^{14}$ which in nominal derivations can be extended with a morpheme $-s$ - (as in Latin dōs, dotis "dowry") or $-n$ - (as in Latin dōnum "gift" < PIE *déh $\left.{ }_{3} r / n-\right) .{ }^{15}$ Note that in decipherment terminology we are dealing here with an object bilingual, as xodooś"pouring vessel" denotes the object on which the legend is written, an oinokhoe,

\footnotetext{
${ }^{7}$ Woudhuizen, Etruscan as a Colonial Luwian, 100.

${ }^{8}$ Woudhuizen, Etruscan as a Colonial Luwian, 398.

${ }^{9}$ Mallory \& Adams, The Oxford Introduction to Proto-Indo-European, 418.

${ }^{10}$ Woudhuizen, Selected Luwian Hieroglyphic Texts, 430.

${ }^{11}$ Woudhuizen, Etruscan as a Colonial Luwian, 450; 464.

${ }^{12}$ Woudhuizen, Carian: On the Luwian-Greek, 9.

${ }^{13}$ Mallory \& Adams, The Oxford Introduction to Proto-Indo-European, 393.

${ }^{14}$ Mallory \& Adams, The Oxford Introduction to Proto-Indo-European, 270.

${ }^{15}$ Cf. Mallory \& Adams, The Oxford Introduction to Proto-Indo-European, 273-274.
} 
which of course also may serve for pouring other liquids than wine, like water (see next entry).

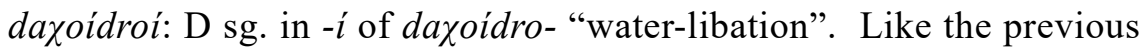
word, daxoidro- is of composite nature. It shows the first element daxo-, the root of which is also present in the verb da - "to dedicate" and the related noun da $\chi \chi$ - "dedication" as attested for C.Ia 3 from Iasos. ${ }^{16}$ This element corresponds to Phrygian da $\chi$ "to place, put; to dedicate" (<PIE * $d^{h} e h_{1}(-k)$ - as in Greek $\tau i ́ \theta \eta \mu 1$ and Latin facere $).{ }^{17} \mathrm{Next}$, as the second element of the com-

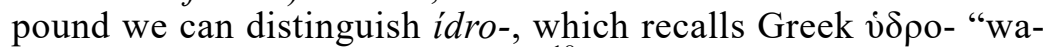
ter", originating from PIE *wódr. ${ }^{18}$ Note that the D sg. in $-i$ was surmised by me as an unwritten iota subscriptum in connection with eqqro $\left(m_{1} s n_{1} a\right)$ "to the great (god)" in C.xx 1 of uncertain origin, nzẽo "to the Nyseian (god)" in C.Ia 3 from Iasos, and mézo "to the god" in C.Ha 1 from Halikarnassos. ${ }^{19}$

padșa: endingless $\mathrm{N}(\mathrm{m} / \mathrm{f}) \mathrm{sg}$. of the TN $\Pi \eta \dot{\delta} \delta \sigma \alpha$. This TN shows a reflex of PIE *ped- "foot" 20 in like manner as Luwian hieroglyphic páta- "place; field, meadow, precinct, plot" (bearing testimony of the vowel $a)^{21}$ and Greek $\pi \varepsilon \delta$ íov "plain, valley". According to Wikipedia, s.v. Pedasa, this place is located between Miletos and Halikarnassos in the west and Stratonikeia in the east, which means precisely in the region of Mylasa. ${ }^{22}$ As the oinokhoe originally served a religious purpose, it lies at hand to assume that it had been dedicated by the community of Pedasa to a sanctuary in the region of the nearby central Mylasa.

edraqa: augmented (e-) 3rd pers. sg. of the past tense in -qa of the verb $d r a$ - "to dedicate". The verbal root $d r a$ - corresponds to Etruscan $t(u) r(u)$ - "to give". ${ }^{23}$ The $3 \mathrm{rd}$ pers. sg. of the past tense of this verb, turuce, has been compared by A.I. Charsekin to the Greek perfect $\delta \varepsilon \delta \omega \rho \eta \kappa \varepsilon$ from $\delta \omega \rho \varepsilon ́ \omega .{ }^{24}$ The latter verb shows the morpheme $-r$ - in like manner as the noun $\delta \tilde{\omega} \rho o v\left(<\mathrm{PIE} * d e ́ h_{3} r / n\right.$ "gift"). ${ }^{25}$ Now, from the perfect $\delta \varepsilon \delta \omega ́ \rho \eta \kappa \varepsilon$ we may perhaps surmise an aorist * $\dot{\delta} \delta \omega \rho \uparrow \kappa \varepsilon$, which would match Carian syncopated edraqa. At any rate, the use of the augment is definitely a Greek feature otherwise unparalleled for the Indo-European Anatolian languages. ${ }^{26}$ Note that the ending of the 3rd pers. sg. of the past

${ }^{16}$ Woudhuizen, Carian: On the Luwian-Greek, 11-12.

${ }^{17}$ Cf. Mallory \& Adams, The Oxford Introduction to Proto-Indo-European, 295.

${ }_{18}$ Mallory \& Adams, The Oxford Introduction to Proto-Indo-European, 125.

${ }^{19}$ Woudhuizen, Carian: On the Luwian-Greek, 11; 12; 14.

${ }^{20}$ Mallory \& Adams, The Oxford Introduction to Proto-Indo-European, 250.

${ }^{21}$ Woudhuizen, Selected Luwian Hieroglyphic Texts, 350.

${ }_{22}^{2}$ Adiego, The Carian Language, 521, Map 1.

${ }^{23}$ Woudhuizen, Etruscan as a Colonial Luwian, 463.

${ }^{24}$ Charsekin, Zur Deutung...; cf. Woudhuizen, Etruscan as a Colonial Luwian, 81.

${ }^{25}$ Mallory \& Adams, The Oxford Introduction to Proto-Indo-European, 273-274.

${ }^{26}$ Woudhuizen, Indo-Europeanization in the Mediterranean, 15-19. 
tense in -qa thus far had been encountered in form of $-q \tilde{e} .^{27}$ It is a moot point whether this, like Etruscan -ce, is a reflex of Greek $-\kappa \varepsilon$ or Luwian $-t a$ and Lycian $-t e$ or $-t \tilde{e}^{28}$ by means of $c / t$-change. ${ }^{29}$

The aforegoing treatment of the Carian inscription from Mylasa shows that the values of the letters of the Carian alphabet as established by me in 2018 are correct. As opposed to this, the current paradigm formed by the "Adiego-Schürr system" leads nowhere.

Furthermore, it may be concluded that 7 th century BC Carian from Caria is much closer related to Etruscan than the later inscriptions would suggest. This comes as no surprise, as substantial colonization of Etruria took place from $c .700 \mathrm{BC}$ onwards and demonstrably involved Luwian population groups from Lydia and Lycia, so may reasonably be assumed to have included those from the intermediate Caria as well (as most tellingly illustrated by the family name Karkana- [< Hittite Karkisa- or Karkiya- "Caria"] attested for inscriptions from Caere). ${ }^{30}$

\section{BIBLIOGRAPHY}

Adiego, Ignacio J. The Carian Language. Handbook of Oriental Studies, Section One: The Near and Middle East 86, Leiden-Boston, 2007.

Charsekin, A.I. Zur Deutung etruskischer Sprachdenkmäler. Untersuchungen zum Römischen Geschichte III, Frankfurt am Main, 1963.

Mallory, James P., \& Adams, Douglas Q. The Oxford Introduction to Proto-Indo-European and the Proto-Indo-European World, Oxford 2007 (Reprinted).

Rix, Helmut, e.a. Etruskische Texte, Editio minor, Band I: Einleitung, Konkordanz, Indices; Band II: Texte. ScriptOralia 23-24, Tübingen 1991.

Türkteki, Sinem, \& Tekoğlu, Recai. "Une inscription Carienne sur oenochoé au musée de Sadberk Hanım.” Kadmos 51, 2012, pp. 99-113.

Woudhuizen, Fred C. Etruscan as a Colonial Luwian Language, Linguistica Tyrrhenica III. Innsbrucker Beiträge zur Kulturwissenschaft, Sonderheft 128, Innsbruck, 2008.

Woudhuizen, Fred C. Selected Luwian Hieroglyphic Texts: The Extended Version. Innsbrucker Beiträge zur Sprachwissenschaft 141, Innsbruck, 2011.

Woudhuizen, Fred C. "Carian: On the Luwian-Greek Interface.” Živa Antika 68, 2018, pp. 5-24.

Woudhuizen, Fred C. Indo-Europeanization in the Mediterranean, with particular attention to the fragmentary languages. PIP-TraCS - Papers in Intercultural Philosophy and Transcontinental Comparative Studies 16, [Haarlem], 2018.

${ }^{27}$ Woudhuizen, Carian: On the Luwian-Greek, 22.

${ }^{28}$ Woudhuizen, Selected Luwian Hieroglyphic Texts, 432.

${ }^{29}$ Woudhuizen, Etruscan as a Colonial Luwian, 181-182.

${ }^{30}$ Rix e.a., Etruskische Texte I, 84; Rix e.a., Etruskische Texte II, Cr 2.4, 2.18, $2.19,2.20,2.34,2.35,6.1$ (all 7th century BC). 
